\title{
BASIC UNIT COST SIMULATION FROM FREE-STALL DESIGN TO DAIRY CATTLE CONFINEMENT USING DIFFERENT CONSTRUCTION TECHNIQUES
}

Doi:http://dx.doi.org/10.1590/1809-4430-Eng.Agric.v36n6p972-983/2016

\section{MARCELO C. RAMOS ${ }^{1 *}$, JACKSON A. BARBOSA $^{2}$}

${ }^{1 *}$ Corresponding author. Universidade Federal de Lavras/ Lavras - MG, Brasil. E-mail: carvalho_marceloc@hotmail.com

ABSTRACT: The ascendancy of milk production in Brazil is due to mainly to the adoption of confinement systems, however, construction quality of these systems impact on milk production. This study aimed to simulate the Basic Unit Cost $\left(\mathrm{BUC} \mathrm{m}^{-2}\right)$, referring to a free-stall design with capacity for 80 animals and different construction techniques, with a database for various budget analysis and investment plans. A budgetary spreadsheet was modeled, allowing simulating the BUC $\mathrm{m}^{-2}$ for different combinations of roof pillars (metallic, wood or reinforced concrete), covering structure (metallic or wood), coverage model (with or without ridge vent), roof tiles (aluminum, cement or ceramic) and masonry (concrete block, ceramic or solid brick). The techniques used were compositions generated by Price Compositions tables for Budgets (TCPO, 2014). The results relating to 2014 and expressed in unencumbered values showed the maximum variation of $29 \%$ in the BUC m$~^{-2}$, establishing a range of $\mathrm{R} \$ 523.96 \mathrm{~m}^{-2}$ to $\mathrm{R} \$ 675.98 \mathrm{~m}^{-2}$ for the free-stall construction.

KEYWORDS: cost breakdown, construction techniques, dairy farms, milk production, rural buildings.

\section{INTRODUCTION}

The ascendancy of milk production in Brazil is due to, mainly, the adoption of confinement systems and with higher production animals. This model has been considered as one of the most attractive options because it offers the best conditions for technological interventions and greater control in the thermal quality of the environment. However, the zootechnical constructions most suitable to the production system demand increasingly different solutions and adaptations needs (LOPES et al., 2012). Productive efficiency in free-stall confinement is highly affected by poor design of the confinement projects, which usually limits interventions in the environment thermal control and disfavor the routine chores in the operation, maintenance, hygiene and animals handling (PERISSINOTTO et al., 2009; OSTOJIĆ-ANDRIĆ et al., 2011).

Researches pointed to the unfeasibility of dairy cattle confinement (BARBOSA et al., 2011), however, it is essential that the project contemplates the use of more sophisticated technical solutions. This usually is not observed in practice, masking the investment analysis by the lack of knowledge of the essential and necessary requirements for the animal health, and increase in production of milk quality (STOCK et al., 2008).

PIRES et al. (2011) corroborated with MILANI \& SOUZA (2010) that the hot weather is the most important factor that contributes to the increase in losses and low productivity, limiting the performance of the most productive animals even in good nutrition conditions or abundant pasture. However, to provide an optimal thermal environment is not easy because it requires a large number of variables to be considered. The authors emphasize the importance in choosing the material used in construction of the confinement environment. Many materials of different species (wood, concrete and metal) are chosen depending on the cost, practicality and reuse opportunities. Furthermore, wood is very sensitive to humidity, which enables the development of macro and microorganisms, making difficult the maintenance and hygiene of the place (PIRES et al., 2011).

For SANTOS et al. (2009), the successful implementation of a project is closely linked to the management of different resources (material, labor, equipment and capital), often subject to limitations and restrictions on the use. In search of the better production efficiency, MATTOS (2010) intensified that first the entrepreneur should plan a construction budget; at the moment that acquires a high degree 
of knowledge on the subject. Even at an estimated level, a budget can be a good source of information and fast preparation (CARDOSO, 2011).

The construction planning must not only consider the time dimension, but a cost estimate for each activity. For a higher accuracy degree, the budget should consider the dependence of variables prices in the market and allow the criteria use to the direct cost calculation (SANTOS et al., 2009).From the project preparation, the budget officer should see all the services and the quantitative involved and quote prices for materials and services, according to the market value, in addition to considering all social laws (SL), additional charges (AC) and bonus for indirect expenses (BIE) (TISAKA, 2011). The aim of this study was to calculate the basic unit cost in $\mathrm{BUC} \mathrm{m}^{-2}$, for different construction techniques of a freestall reference project, also offering a database for budget analysis and investment plans.

\section{MATERIAL AND METHODS}

This research was based on the free-stall design of the research center from the Federal University of Lavras, Minas Gerais (UFLA). It was used the architectural, structural, electrical and hydraulic projects that compose the documental file attached to the 12908/2014 bidding process of Educational Scientific and Cultural Development Foundation (FUNDEC), whose bidding contest in Competition mode $\mathrm{n}^{\circ} 001 / 2014$, of lowest global price type and under contract scheme by unit price occurred on 02/19/2015. Thus, the value of the company awarded for this agreement was unencumbered and compared to the amount foreseen in the budget worksheet generated for the specific purposes of this research.

The ground plan is located at Fazenda Palmital, Ijaci, MG, $21^{\circ} 10^{\prime} 12^{\prime}$ S latitude, $44^{\circ} 55^{\prime} 30^{\prime \prime}$ $\mathrm{W}$ longitude, altitude of $889 \mathrm{~m}$ and tropical climate. The rainfall in the region is $1529.7 \mathrm{~mm}$ per year with an average annual temperature of $19.4^{\circ} \mathrm{C}$ (IBGE, 2011).

First, the free-stall reference project has been designed for a capacity of 80 animals grouped into four groups of 20 animals and free, individual stalls with rubber mattress to improve the animal comfort (CORDOBA et al., 2012) and the energy system efficiency (RAMOS et al., 2014) when compared to the sand beds. Then, based on the reference project for 80 animals, were estimated the BUC $\mathrm{m}^{-2}$ for capacities of 40 and 120 animals.

Figure (1) is a sketch of the free-stall reference project, composed of 80 free and individual stalls of $2.86 \mathrm{~m}^{2}$ animal ${ }^{-1}$ with flying type bed separator; $557 \mathrm{~m}^{2}$ of collective area with access to food and retractable stainless steel drinking fountains.

The animal confinement area is attached to the animals' movement corridor to the waiting corral, with $63.5 \mathrm{~m}$ of length and $2 \mathrm{~m}$ of wide. This area totaled $237.75 \mathrm{~m}^{2}$ of protection grating and $65.4 \mathrm{~m}^{2}$ of metallic gates, both specified in round tube of galvanized steel (2" and 4 " inches).

Attach to the confinement area, a collective area of $375 \mathrm{~m}^{2}$ was designed, being: $136.5 \mathrm{~m}^{2}$ of exclusive use of the milking parlor and waiting corral; $171.0 \mathrm{~m}^{2}$ of corridors with foot washing and foot bath, essential elements to minimize the injury effects on the hoof (COOK \& NORDLUND, 2009). The collective area was composed of $60 \mathrm{~m}^{2}$ of building in masonry for administrative use, being: $9 \mathrm{~m}^{2}$ for deposit; $10.5 \mathrm{~m}^{2}$ for laboratory; $10.5 \mathrm{~m}^{2}$ for office; $13 \mathrm{~m}^{2}$ for milk room; $8.5 \mathrm{~m}^{2}$ for bathroom; $8.5 \mathrm{~m}^{2}$ for machine's room and $7.5 \mathrm{~m}^{2}$ for people movement (front of the shed). The collective area has $173.79 \mathrm{~m}^{2}$ of metallic protection grating and $30.39 \mathrm{~m}^{2}$ of metallic gates.

The total paved area of the reference project was $1,350 \mathrm{~m}^{2}$, being $1,638 \mathrm{~m}^{2}$ of covered area, the structure being supported by 34 pillars spaced every $5.5 \mathrm{~m}$ with a ceiling height of $5 \mathrm{~m}$. The cover was designed with aluminum tile and thickness of $0.5 \mathrm{~mm}$, model without ridge vent. 


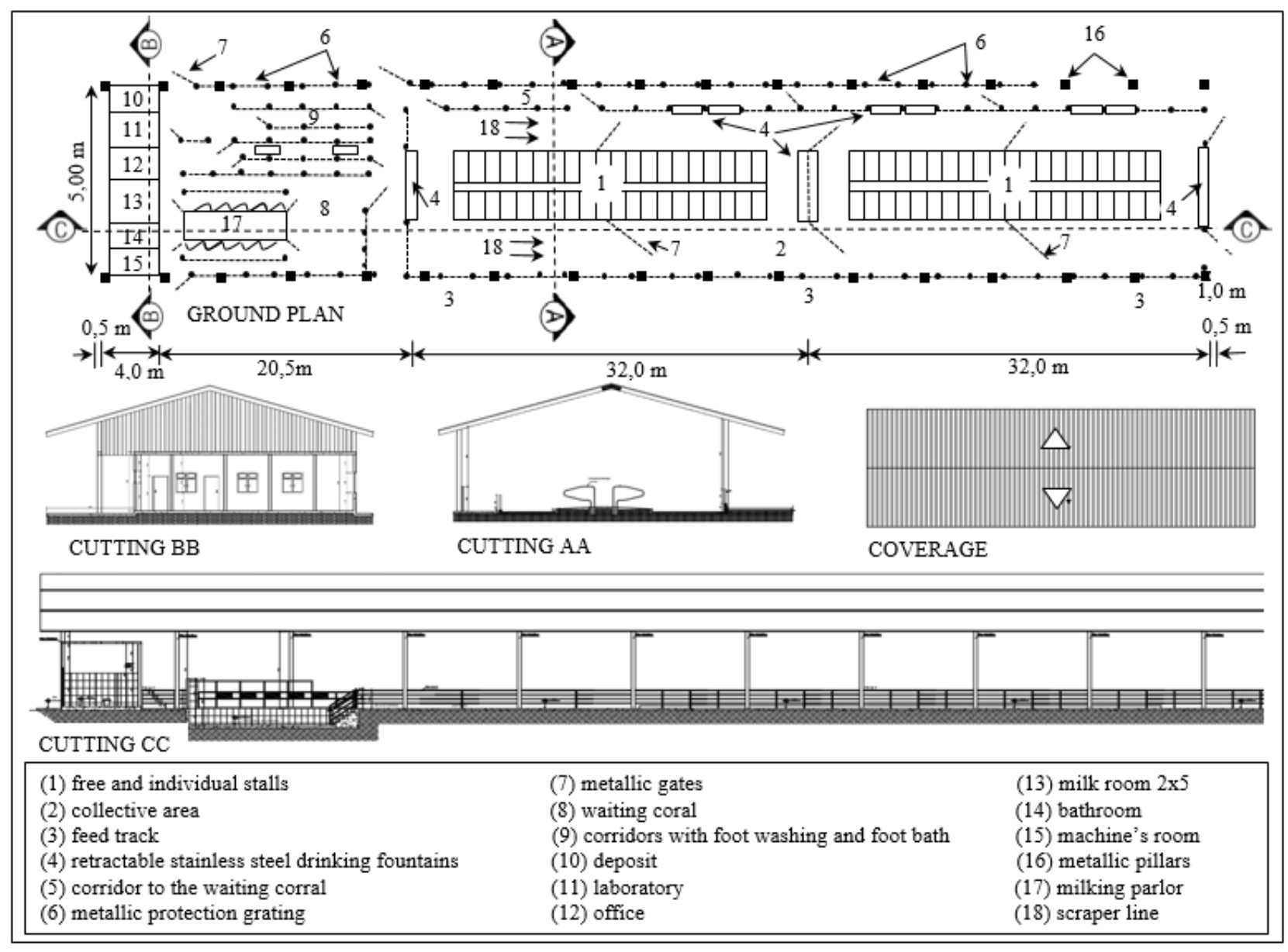

FIGURE 1. Free-stall reference project sketch for the capacity of 80 animals.

The budget spreadsheet of the reference project was estimated by activities (SANTOS et al., 2009), starting with pre-installation of the water points and electricity, land clearing, work lease and land movement. The calculations followed the paved area dimensions of $1,350 \mathrm{~m}^{2}$.

The infrastructure included the manual and mechanized digging of ditches and belled piles in open sky (diameter of $0.3 \mathrm{~m}$, depth of $1 \mathrm{~m}$ ), reinforcement steel frame and concrete launch in the foundations, grade beam, foundation masonry, ballast of gravel and concrete. The superstructure totaled the preparing and launching of concrete fck $30 \mathrm{MPa}$, wood forms, slabs shoring and the structure pillars, which are calculated for structure in reinforced concrete, in wood or in metallic profile. For masonry, it was considered the seals in concrete block, hollow ceramic block and solid brick made of clay and also the lintels, sills and divisions in granite to the bathroom.

The cover structure for the free-stall was classified in a way to enable the integration of different materials (steel and wood). The shears length was designed to be calculated according to the span of the free-stall (front), ranging from 15, 20, 25 and $30 \mathrm{~m}$. The wooden structure has been designed to the maxim span up of $15 \mathrm{~m}$ wide; above this value the wood option was not considered. The model for the metallic roof considered the two waters system with and without ridge vent.

The tiles for the coverage, one of the most responsible for thermal comfort (TONOLI et al., 2011; SAMPAIO et al., 2011), were specified as follows: aluminum tile in wavy and trapezoidal profile with thickness of $0.5 \mathrm{~mm}$ (painted or varnished); aluminum thermal-acoustic tile in trapezoidal profile with thickness of $30.0 \mathrm{~mm}$; fiber cement tile in wavy profile and thickness of 6 $\mathrm{mm}$ and French type ceramic tile (clay).

The roof slope follows the technical specifications of TCPO (2014), being 10\% for aluminum and thermal-acoustic tiles; $27 \%$ for fiber cement tiles and $35 \%$ for ceramic tiles. It was considered the finishing for the coverage with settling and placing of the ridge tiles for the ceramic, fiber cement and aluminum tiles. 
The shed floor area for the animals movement and rest was designed in 1,269.12 $\mathrm{m}^{2}$, coated with $5 \mathrm{~cm}$ in gravel layer, $5 \mathrm{~cm}$ in concrete and $8 \mathrm{~cm}$ in concrete fck of $20 \mathrm{MPa}$, with double reinforcement in steel frame CA-60 (4.20 mm of diameter and mesh of $10 \times 10 \mathrm{~cm})$, provided with channels for washing and water flow, seeking to decrease the contamination levels caused by animal waste (RUUD et al., 2010). To the area for the stalls (cow beds) were provided $124.8 \mathrm{~m}^{2} \mathrm{of}$ rubber mattress of $7 \mathrm{~cm}$, aiming to bring the comfort provided by traditional sand beds and also to minimize the claudication effect, provided by the concrete floor (CECCHIN et al., 2014; MITEV et al., 2012; COOK \& NORDLUND, 2009).

In the feed track (without animals traffic) it was considered $202.5 \mathrm{~m}^{2}$ of cemented floor with 3 $\mathrm{cm}$ of cement mortar (1:3 ratio), and waterproofing. In the inner area of the free-stall (no traffic of animals) for the administrative facilities, machine's room, milk room and the parlor pit, was predicted $80.88 \mathrm{~m}^{2}$ of enameled ceramic floor and placed with adhesive mortar.

The coating of the internal walls in the administrative areas (office and machine's room) and every area of external walls received compositions of roughcast and plaster, both with 1:3 ration and thickness of $5 \mathrm{~mm}$. The areas for the storage, laboratory, machine's room, bathroom, milk room and the mechanized parlor pit received compositions of roughcast and plaster. For the plastering was used the 1:3 ration and thickness of $30 \mathrm{~mm}$, followed by tile placing with adhesive mortar.

The steel and wood frames of the administrative area were calculated according to the dimensions and expected quantities of the architectural design, being the windows in steel and aluminum with $5 \mathrm{~mm}$ of crystal glass. The doors were designed with $210 \mathrm{~cm}$ x $90 \mathrm{~cm}$, made with jambs, casing and hardware.

In the finishing phase, it was considered the paintings of the walls, frames, grids and metallic gates, beyond the supply and installation of the retractable stainless steel drinking fountains, bed separator (flying type), granite countertops for the laboratory and sink (with stainless central basin), marble countertops for sinks, bathroom faucets and fixtures.

For the hydraulic installations, it was considered the supply of equipment and service for domestic water supply in brown PVC pipes and white PVC for the sanitary sewer collection system and rainwater drainage system with rainwater reuse, and accessories for installation and water reservoirs, according to the hydraulic design reference. The electrical installations contemplated the material and service supply for air protection system, power input, electrical conductors, sockets, switches and indoor and outdoor lighting of the free-stall. It was not predicted the installation of structured cabling, protection system to fire, environmental controllers and installation of the equipment (electrical and mechanical) in the parlor room.

Based on the reference project and survey all the quantitative, a budget spreadsheet was modeled with the technical compositions generated by Price Compositions Tables for Budgets (TCPO, 2014). The unit values of supplies and labor followed the prices quoted for the cities of São Paulo, Belo Horizonte, Curitiba and Goiânia. The budget spreadsheet was developed in Microsoft Office Excel, which choice was due to easy import the compositions generated by TCPO-2014 and the dimensions changes of the construction and materials used in the construction, to promote construction costs analysis for projects with modular capacities of 40, 80 and 120 animals.

The results validation occurred by comparing the Basic Unit Cost calculated by the Union of Construction Industry (SINDUSCON, 2014) in the first quarter of 2014 and the budget unit values that compose the public bidding documents folder to the cities of Sao Paulo, Belo Horizonte, Curitiba and Goiania, excluding of this spreadsheet the discount presented by the company awarded, the Social Laws, Administrative fees, Bonus for Indirect Expenditures and other integral parts of the overall design, not included in this research.

\section{RESULTS AND DISCUSSION}

The budget summary spreadsheet for the implementation cost analysis of the free-stall reference project for the capacity of 80 animals, front span of $15 \mathrm{~m}$, with foundation for metallic 
structure and coverage without ridge vent and masonry in concrete block was totaled and presented in local currency (R\$) and in US dollar (US\$) quoted in R 2.26 on March 31, 2014, according to Table 1.

TABLE 1. Implementation cost of free-stall reference project - 80 animals capacity.

\begin{tabular}{|c|c|c|c|c|}
\hline \multirow{2}{*}{$\begin{array}{c}\text { Cost by activities } \\
(\mathrm{R} \$)\end{array}$} & \multicolumn{4}{|c|}{ Cost $(\mathrm{R} \$)$ by regions } \\
\hline & São Paulo & Belo Horizonte & Curitiba & Goiânia \\
\hline Initial services & $10,488.19$ & $10,066.19$ & $10,050.21$ & 10.249 .27 \\
\hline Infrastructure & $134,214.15$ & $121,831.97$ & $119,894.09$ & 122.467 .91 \\
\hline Superstructure & $46,154.65$ & $42,921.02$ & $45,997.90$ & 43.850 .62 \\
\hline Masonry & $10,470.00$ & $9,902.47$ & $10,095.96$ & 8.452 .72 \\
\hline Coverage & $274,548.35$ & $257,644.50$ & $246,667.22$ & 273.042 .44 \\
\hline Floor and coatings & $141,977.54$ & $137,121.34$ & $132,022.05$ & 129.990 .72 \\
\hline Metallic frames & $78,179.02$ & $71,625.63$ & $77,395.82$ & 69.745 .50 \\
\hline Painting (wall/metal) & $9,957.96$ & $9,211.16$ & $9,893.83$ & 8.799 .77 \\
\hline Ware and metals & $4,160.54$ & $3,992.99$ & $3,906.88$ & 4.491 .84 \\
\hline Glasses & 667.86 & 774.10 & 881.68 & 856.92 \\
\hline Electrical facilities & $45,000.00$ & $45,000.00$ & $45,000.00$ & $45,000.00$ \\
\hline Hydraulic installations & $40,000.00$ & $40,000.00$ & $40,000.00$ & $40,000.00$ \\
\hline Total $(\mathrm{R} \$)$ & $795,818.25$ & $750,091.36$ & $741,805.64$ & $756,947.71$ \\
\hline $\mathrm{BUC} \mathrm{m}^{-2}(\mathrm{R} \$)$ & 589.49 & 555.62 & 549.49 & 560.70 \\
\hline $\mathrm{R} \$$ animal $^{-1}$ & $9,947.73$ & $9,376.14$ & $9,272.57$ & $9,461.85$ \\
\hline Total (US\$) & $351,758.42$ & $331,546.74$ & $327,884.39$ & $334,577.31$ \\
\hline $\mathrm{BUC} \mathrm{m}^{-2}$ (US\$) & 260.56 & 245.59 & 242.88 & 247.84 \\
\hline${\mathrm{US} \$ \text { animal }^{-1}}$ & $4,396.98$ & $4,144.33$ & $4,098.55$ & $4,182.22$ \\
\hline
\end{tabular}

Dollar value on March 31, $2014=\mathrm{R} \$ 2.26$

The results highlighted the coverage as responsible for the largest share in the total cost of the work, representing $34.5 \%$ on average for all locations. The floors and coatings participated $17.8 \%$ on average of the total cost, yet, in this stage of the work, it was observed a higher consumption of labor, which caused major variations by location in the cost of this stage, caused by the hour $\operatorname{man}^{-1}$ value and different labor charges.

In descending order, the hour ${ }^{-1}$ man values used for the bricklayer function were $\mathrm{R} \$ 5.68$ in Curitiba, R\$ 5.31 in São Paulo, R\$ 4.71 in Belo Horizonte and R\$ 4,41in Goiania. For the servant function, the hour ${ }^{-1}$ man values used were $\mathrm{R} \$ 4.45$ in São Paulo, $\mathrm{R} \$ 4.04$ in Curitiba, $\mathrm{R} \$ 3.08$ in Belo Horizonte and R\$ 2.89 in Goiânia. In Curitiba, although the BUC $\mathrm{m}^{-2}$ is lower than in São Paulo, the hour man ${ }^{-1}$ value of bricklayer and locksmith was $7 \%$ higher than in São Paulo.

The washed sand stood out in cost among the steps that consumed greater amount of this aggregate (masonry, floors and coatings). In São Paulo, the washed sand medium type had the highest unit value, being $\mathrm{R} \$ 101.68 \mathrm{~m}^{-3}$, followed by $\mathrm{R} \$ 79.67 \mathrm{~m}^{-3}$ in Belo Horizonte, $\mathrm{R} \$ 54.27 \mathrm{~m}^{-3}$ in Curitiba and $\mathrm{R} \$ 50.56 \mathrm{~m}^{-3}$ in Goiânia. The unit price value of sand was influenced by environmental exploitation characteristics, which according to MECHI \& SANCHES (2010), sand exploitation generates positive impacts on society, but also contributes to changes in the environmental characteristics of the exploitation place, degrading riparian forests and causing siltation and pollution of rivers.

Also in Table 1, the infrastructure was responsible $16.4 \%$ on average of the total cost. This result is justified by the applied concrete volume of $30 \mathrm{MPa}$ and reinforcement steel frame for CA50 concrete in compliance with the foundation project. Thus, BUC $\mathrm{m}^{-2}$ relating to free-stall reference project, was higher for the State of São Paulo $\left(\mathrm{R} \$ 589.49 \mathrm{~m}^{-2}\right)$, followed by Goiânia (R\$ $\left.560.70 \mathrm{~m}^{-2}\right)$, Belo Horizonte $\left(\mathrm{R} \$ 555.62 \mathrm{~m}^{-2}\right)$ and Curitiba $\left(\mathrm{R} \$ 549.49 \mathrm{~m}^{-2}\right)$. But the cost per animal $\left(\mathrm{R} \$\right.$ Animal $\left.^{-1}\right)$ was little influenced by regional characteristics. 
The sum of the partial construction cost considering the infrastructure, coverage, floors and coatings, represented $68.7 \%$ on average of the total cost of the work, and other items represented the cost of 30.80\% in São Paulo, 31.13 \% in Belo Horizonte, 32.79\% in Curitiba and 30.58\% in Goiânia, as shown in Figure 2.

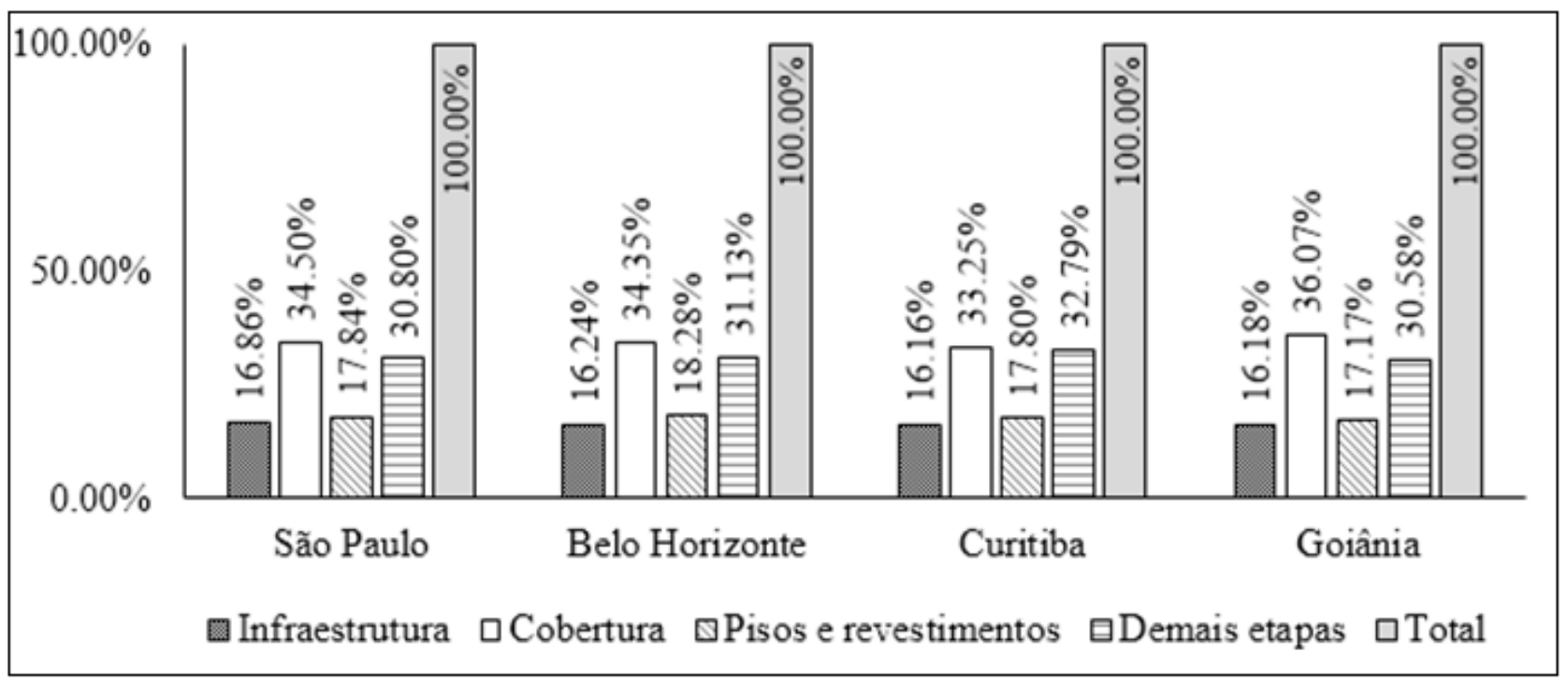

FIGURE 2. Relative cost percentage from free-stall reference project - 80 animals' capacity.

In April 2014, according to the Union of Construction Industry (SINDUSCON, 2014), the unencumbered value in BUC $\mathrm{m}^{-2}$ (without Social Laws and Benefits and Indirect Costs) for the construction of $1,000 \mathrm{~m}^{2}$ of Industrial Shed (IS) in metallic structure, without foundation, with trapezoidal metallic tile of $0.5 \mathrm{~mm}$, administrative area, two bathrooms, a dressing room and a deposit, was R\$ $580.83 \mathrm{~m}^{-2}$ for São Paulo, $\mathrm{R} \$ 558.97 \mathrm{~m}^{-2}$ for Belo Horizonte, $\mathrm{R} \$ 585.18 \mathrm{~m}^{-2}$ for Curitiba and $\mathrm{R} \$ 547.67 \mathrm{~m}^{-2}$ for Goiania. Comparing the results of this research to the figures released by SINDUSCON, 2014 (Table 2) it is clear that the BUC $\mathrm{m}^{-2}$ of the reference project was below the values mentioned by SINDUSCON (2014) for all regions, in other words: $18.52 \%$ in São Paulo, 20.11\% in Belo Horizonte, 27.03\% in Curitiba and $16.53 \%$ in Goiânia. These budgetary differences were strongly influenced by no consideration of the foundation Industrial Shed cost (IS) released by the SINDUSCON (2014) regarding to each location searched.

Considering some other differences in the constructive characteristics of the Industrial Shed (SINDUSCON, 2014) with the reference project, such as the closure of the entire perimeter of the free-stall with sealing masonry in concrete block, tie beams, coating with roughcast, plaster and painting, it was noticed a better approximation to the indices published by SINDUSCON (2014). The approaching average was $5.55 \%$ for São Paulo, Belo Horizonte and Goiânia, remaining the highest percentage in Curitiba (12.45\%). By adding to the reference project, the foundation cost and the side closing in masonry cost, the results showed that the BUC $\mathrm{m}^{-2}$ exceeds the average values mentioned by SINDUSCON (2014) of $9.1 \%$ for São Paulo, Belo Horizonte and Goiânia and 2.05\% for Curitiba. It can be noticed in this analysis that the foundation cost is specific to each type of project and its structural characteristics and should be analyzed separately in order to obtain better budgetary results. 
TABLE 2. Basic Unit Cost (BUC $\mathrm{m}^{-2}$ ) from free-stall reference project - 80 animals' capacity (with and without foundation).

\begin{tabular}{lcccc}
\hline & \multicolumn{3}{c}{ Cost (R\$) by regions } \\
\hline Structure without foundation & São Paulo & $\begin{array}{c}\text { Belo } \\
\text { Horizonte }\end{array}$ & Curitiba & Goiânia \\
\hline Industrial Shed (SINDUSCON, 2014) (R\$) & 580.83 & 558.97 & 585.18 & 547.67 \\
$\begin{array}{l}\text { Free-stall (reference project) (R\$) } \\
\text { Free-stall (reference project with side closing in }\end{array}$ & 490.08 & 465.38 & 460.68 & 469.99 \\
masonry) (R\$) & 553.37 & 522.20 & 520.37 & 523.28 \\
\hline Structure with foundation & & & & \\
\hline $\begin{array}{l}\text { Free-stall (reference project) (R\$) } \\
\text { Free-stall (reference project with side closing in } \\
\text { masonry) (R } \$)\end{array}$ & 6399.49 & 555.62 & 549.49 & 560.70 \\
\hline
\end{tabular}

By changing the shed dimensions for spans of 15, 20, 25 and $30 \mathrm{~m}$, maintaining the same paved area of the reference project, was observed, in Table 3, a slight reduction in BUC $\mathrm{m}^{-2}$ when the span from the shed increased.

This reduction occurred due to the reduction in the shed length, reflecting in the reduction of foundation costs, but on the other hand caused an increase in the structure cost for larger spans. Unlike this model, the structure with ridge vent caused a steady increase for all coverage spans, on average of $7.94 \%$ (span of $15 \mathrm{~m}$ ); 8.67\% (span of $20 \mathrm{~m}$ ); $7.08 \%$ (span of $25 \mathrm{~m}$ ) and $10.14 \%$ (span of $30 \mathrm{~m})$.

TABLE 3. Basic Unit Cost $\left(\right.$ BUC m$\left.^{-2}\right)$ from free-stall reference project to 15, 20, 25 and $30 \mathrm{~m}$ span - 80 animals' capacity (with and without ridge vent).

\begin{tabular}{ccccc}
\hline & \multicolumn{4}{c}{ Cost $(\mathrm{R} \$)$ by regions } \\
$\begin{array}{c}\text { Front }(\mathrm{m})- \\
\text { without ridge vent }\end{array}$ & São Paulo & Belo Horizonte & Curitiba & Goiânia \\
\hline 15 & 589.49 & 555.62 & 549.49 & 560.70 \\
20 & 578.74 & 545.48 & 538.48 & 550.84 \\
25 & 586.85 & 552.72 & 544.25 & 559.57 \\
30 & 587.13 & 552.88 & 544.01 & 560.09 \\
\hline Front $(\mathrm{m})$-with ridge vent & & & & \\
\hline 15 & 636.93 & 599.07 & 590.38 & 608.14 \\
20 & 629.58 & 592.04 & 582.31 & 601.68 \\
25 & 628.90 & 591.23 & 580.50 & 601.62 \\
30 & 647.42 & 608.09 & 595.99 & 620.38 \\
\hline
\end{tabular}

The tiles for coverage offer numerous advantages for the environmental thermal control, and they were combined with metallic and/or wood structures and profiles. But the best choice should be one that will provide the best cost benefit, because in accordance with TONOLI et al. (2011), SAMPAIO et al. (2011), the ceramic tile has lower thermal dissipation, but increases the weight of the structure and requires a more robust structure to support the load in greater spans and without support, also hindering the maintenance and cleaning. The aluminum tile is lighter, easy to maintain, but it generates a lot of noise on rainy days and dispels inner heat to the environment. The option of metallic coverage tile with ridge vent minimizes the effects of the aluminum tiles thermal dissipation but increases the structure cost. The thermal-acoustic tile is the most efficient, but raised the BUC m$~^{-2}$ in $10.45 \%$ for São Paulo, $8.89 \%$ for Belo Horizonte, $10.03 \%$ for Curitiba and $7.23 \%$ for Goiânia.

Figures 3, 4 and 5 refer to the BUC $\mathrm{m}^{-2}$ for different construction techniques, which regional characteristics applied to the supplies cost, labor and services caused variations in CUB $\mathrm{m}^{-2}$ for each 
researched area. Simulating changes in combinations of metallic, concrete or wood pillars, with metallic or wood structures and alternating the coverage with aluminum, thermal-acoustic, fiber cement or ceramic tiles, was verified that the region of São Paulo had the highest BUC m${ }^{-2}$ (R\$ $675.98 \mathrm{~m}^{-2}$ ) by combining wooden pillar with wooden structure and thermal-acoustic or ceramic tile (Figure 3). In this case, the increase in the cost of the thermal-acoustic tile when compared to the ceramic tile was proportional to the increase in the wood frame cost for ceramic tiles. For the lowest BUC $\mathrm{m}^{-2}$, Curitiba showed the value of $\mathrm{R} \$ 523.96 \mathrm{~m}^{-2}$, by combining concrete pillar with wooden structure and fiber cement tile (Figure 4).

When comparing the unit cost of all the options referred in Figures 3, 4 and 5, a variation of $29.01 \%$ was observed between the highest and lowest value for BUC $\mathrm{m}^{-2}$, demonstrating the impact that the choice of material, labor and the construction technique will cause in the budget of the work. The other BUC $\mathrm{m}^{-2}$ presented were proposed as financial indicators for budget analysis and investment plans.

\begin{tabular}{|c|c|c|c|c|c|c|c|}
\hline \multicolumn{8}{|l|}{ RS 750.00} \\
\hline \multicolumn{8}{|l|}{ R\$ 500.00} \\
\hline \multicolumn{8}{|l|}{ R\$ 250.00} \\
\hline \multicolumn{8}{|l|}{ RS 0.00} \\
\hline & $\begin{array}{l}\text { PMT } \\
\text { EMT }\end{array}$ & PMT & $\begin{array}{l}\text { PMT } \\
\text { FMT }\end{array}$ & $\begin{array}{l}\text { PMT } \\
\text { EMD }\end{array}$ & $\begin{array}{l}\text { PMT } \\
\text { EMD }\end{array}$ & $\begin{array}{l}\text { PMT } \\
\text { EMD }\end{array}$ & PMT \\
\hline & EMI & EMT TFB & $\begin{array}{ll}\text { EMI } \\
\text { ETS } 1200\end{array}$ & END & ENE & EMD & EMD \\
\hline & $\begin{array}{c}1 \mathrm{AL} 0.5 \\
\mathrm{~mm}\end{array}$ & $6.0 \mathrm{~mm}$ & $\begin{array}{l}\text { 11A } 30.0 \\
\mathrm{~mm}\end{array}$ & $\begin{array}{c}1 \mathrm{AL} 0.5 \\
\mathrm{~mm}\end{array}$ & $\begin{array}{c}1 \mathrm{FB} 0.0 \\
\mathrm{~mm}\end{array}$ & $\begin{array}{l}11 \mathrm{~A} 30.0 \\
\mathrm{~mm}\end{array}$ & TCE - \\
\hline ๑São Paulo & 589.49 & 586.72 & 651.11 & 611.10 & 608.32 & 672.72 & 672.86 \\
\hline$\square$ Belo H. & 555.62 & 555.46 & 605.01 & 585.05 & 584.89 & 634.44 & 643.38 \\
\hline Q Curitiba & 549.49 & 544.32 & 604.59 & 554.59 & 549.42 & 609.69 & 582.24 \\
\hline 日Goiânia & 560.70 & 558.05 & 601.23 & 577.03 & 574.37 & 617.56 & 620.09 \\
\hline \multirow{2}{*}{\multicolumn{2}{|c|}{$\begin{array}{l}\mathrm{PMT}=\text { metallic pillar } \\
\mathrm{EMT}=\text { metallic structure }\end{array}$}} & \multirow{2}{*}{\multicolumn{4}{|c|}{$\mathrm{TAL}=$ aluminum tile $-0.5 \mathrm{~mm}$}} & \multicolumn{2}{|c|}{$\mathrm{TCE}=$ ceramic tile } \\
\hline & & \multirow{2}{*}{\multicolumn{4}{|c|}{ TTA $=$ thermal-acoustic tile $-30 \mathrm{~mm}$}} & & \\
\hline \multicolumn{2}{|c|}{ EMD = wood structure } & & & & & \multicolumn{2}{|c|}{ (*) Data for 2014} \\
\hline
\end{tabular}

FIGURE 3. Basic Unit Cost $\left(\mathrm{BUC} \mathrm{m}^{-2}\right)$ from free-stall design with metallic pillars and with changes in the structure and roof tiles.

\begin{tabular}{|c|c|c|c|c|c|c|c|}
\hline \multirow[t]{2}{*}{$\begin{array}{r}\text { RS } 750.00 \\
\text { RS } 500.00 \\
\text { RS } 250.00 \\
\text { RS } 0.00\end{array}$} & 目 & & & & & & \\
\hline & $\begin{array}{c}\text { PMD } \\
\text { EMT TAL } \\
0.5 \mathrm{~mm}\end{array}$ & $\begin{array}{c}\text { PMD } \\
\text { EMT TFB } \\
6.0 \mathrm{~mm}\end{array}$ & $\begin{array}{c}\text { PMD } \\
\text { EMT TTA } \\
30.0 \mathrm{~mm}\end{array}$ & $\begin{array}{c}\text { PMD } \\
\text { EMD } \\
\text { TAL } 0.5 \\
\text { mm }\end{array}$ & $\begin{array}{c}\text { PMD } \\
\text { EMD TFB } \\
6.0 \mathrm{~mm}\end{array}$ & $\begin{array}{c}\text { PMD } \\
\text { EMD } \\
\text { TTA } 30.0 \\
\text { mm }\end{array}$ & $\begin{array}{c}\text { PMD } \\
\text { EMD TCE } \\
-\end{array}$ \\
\hline$\square$ São Paulo & 594.77 & 604.08 & 656.39 & 614.36 & 611.59 & 675.98 & 675.98 \\
\hline$\square$ Belo H. & 562.53 & 574.42 & 611.91 & 590.77 & 590.61 & 640.16 & 649.77 \\
\hline Curitiba & 544.28 & 547.47 & 599.39 & 543.57 & 538.40 & 598.68 & 566.70 \\
\hline Goiânia & 567.29 & 576.68 & 607.82 & 582.28 & 579.63 & 622.81 & 625.85 \\
\hline \multicolumn{2}{|c|}{$\begin{array}{l}\mathrm{PMD}=\text { wood pillar } \\
\mathrm{EMT}=\text { metallic structure } \\
\mathrm{EMD}=\text { wood structure }\end{array}$} & \multicolumn{4}{|c|}{$\begin{array}{l}\mathrm{TAL}=\text { aluminum tile }-0.5 \mathrm{~mm} \\
\text { TFB }=\text { fiber cement tile }-6.0 \mathrm{~mm} \\
\text { TTA }=\text { thermal-acoustic tile }-30 \mathrm{~mm}\end{array}$} & \multicolumn{2}{|c|}{$\mathrm{TCE}=$ ceramic tile } \\
\hline
\end{tabular}

FIGURE 4. Basic Unit Cost (BUC $\mathrm{m}^{-2}$ ) from free-stall design of wooden pillars and structure and roof tiles changes. 


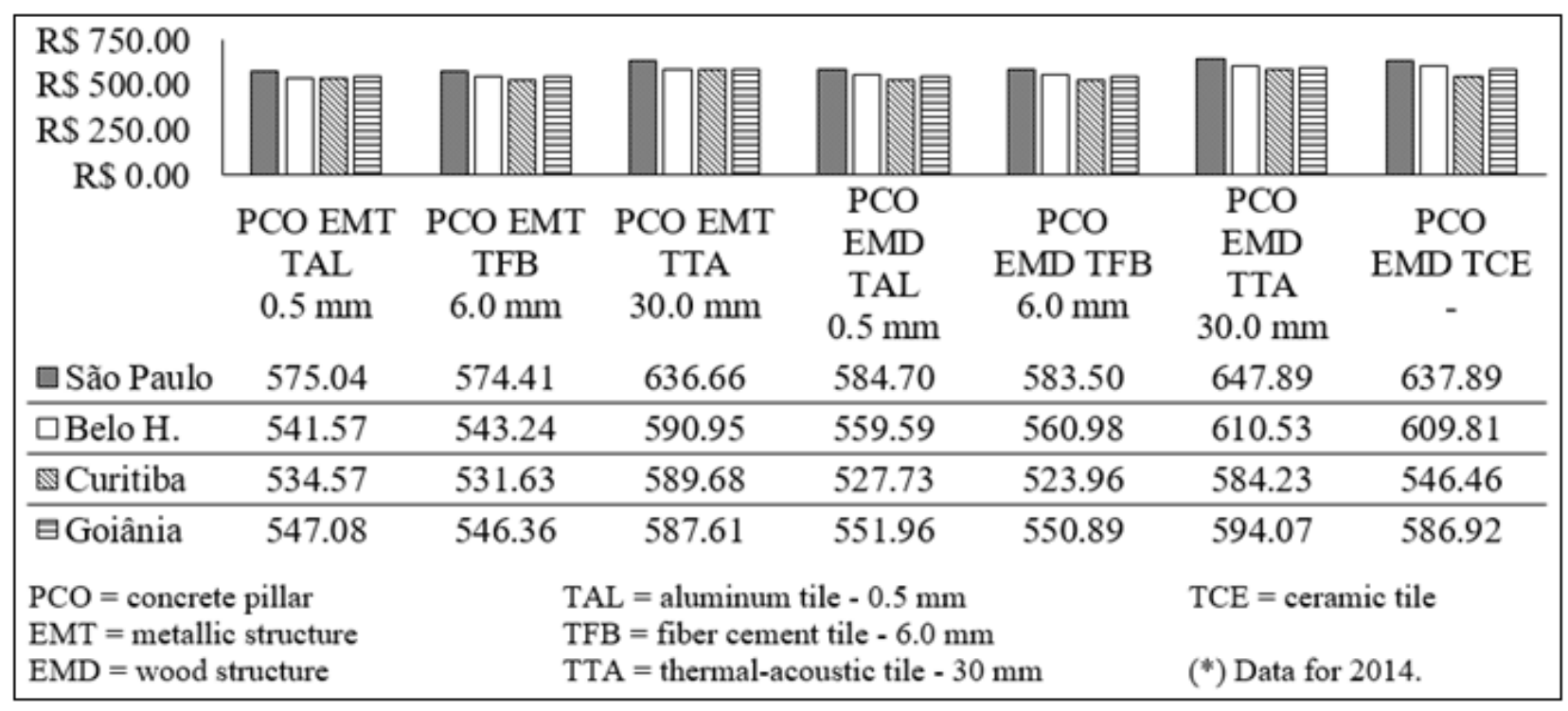

FIGURE 5. Basic Unit Cost $\left(\mathrm{BUC} \mathrm{m}^{-2}\right)$ from free-stall design of concrete pillars and structure and roof tiles changes.

Changing the reference project installation capacity for 40, 80 or 120 animals (Table 4), it was obtained an average reduction of $27.16 \%$ in the total cost per animal, when the capacity rises from 40 to 80 animals justified by better use of collective facilities. For maximum capacity of 120 animals, the average total cost per animal reduced by 36.03 and $12.18 \%$ when compared respectively with the minimum capacity of 40 and an average of 80 animals.

TABLE 4. Basic Unit Cost (BUC $\mathrm{m}^{-2}$ ) from free-stall reference project to 40, 80 or 120 animals capacities.

\begin{tabular}{|c|c|c|c|c|}
\hline \multirow{2}{*}{ Capacity (animals) } & \multicolumn{4}{|c|}{ Cost $(\mathrm{R} \$)$ by regions } \\
\hline & São Paulo & Belo Horizonte & Curitiba & Goiânia \\
\hline \multicolumn{5}{|c|}{ Total cost $(\mathrm{R} \$)$} \\
\hline 40 & $544,670.60$ & $515,120.90$ & $509,911.32$ & $520,268.48$ \\
\hline 80 & $795,818.25$ & $750,091.36$ & $741,805.64$ & $756,947.71$ \\
\hline 120 & $1,050,080.20$ & $987,751.63$ & $976,908.75$ & $996,288.83$ \\
\hline \multicolumn{5}{|c|}{ Total cost per $\mathrm{m}^{2}(\mathrm{R} \$)$} \\
\hline 40 & 648.42 & 613.24 & 607.04 & 619.37 \\
\hline 80 & 589.49 & 555.62 & 549.49 & 560.70 \\
\hline 120 & 564.56 & 531.05 & 525.22 & 535.64 \\
\hline \multicolumn{5}{|c|}{ Total cost per animal $(\mathrm{R} \$)$} \\
\hline 40 & $13,616.76$ & $12,878.02$ & $12,747.78$ & $13,006.71$ \\
\hline 80 & $9,947.73$ & $9,376.14$ & $9,272.57$ & $9,461.85$ \\
\hline 120 & $8,750.67$ & $8,231.26$ & $8,140.91$ & $8,302.41$ \\
\hline
\end{tabular}

Regarding the types of masonry, the use of concrete block, clay solid brick or ceramic with hole, caused little significant impact on BUC $\mathrm{m}^{-2}$ (Table 5), and should be assessed in accordance with the best logistics and desirable thermal characteristics. 
TABLE 6. Basic Unit Cost (BUC $\mathrm{m}^{-2}$ ) from free-stall reference project to different types of masonry -80 animals' capacity.

\begin{tabular}{lcccc}
\hline \multirow{2}{*}{\multicolumn{1}{c}{ Masonry type }} & \multicolumn{4}{c}{ Cost (R\$) by regions } \\
\cline { 2 - 5 } & São Paulo & Belo Horizonte & Curitiba & Goiânia \\
\hline Concrete block (R\$) & 589.49 & 555.62 & 549.49 & 560.70 \\
Ceramic block (with holes) (R\$) & 587.83 & 554.02 & 547.13 & 558.66 \\
Solid brick (clay) (R\$) & 591.55 & 557.35 & 551.49 & 563.08 \\
\hline
\end{tabular}

The budget spreadsheet of the free-stall reference project for capacity of 80 animals considered all labor values and unencumbered materials, being: free from any administrative fees, labor costs, local, state and federal taxes. The values expressed in this research, and compared with the Union of Construction Industry (SINDUSCON, 2014) were also compared to unit values described in the budget spreadsheet for public bidding and the BUC $\mathrm{m}^{-2}$ of the winning bid and adjudicated, which was $\mathrm{R} \$ 562.88 \mathrm{~m}^{-2}$.Value almost equal to the average of $\mathrm{R} \$ 563.88 \mathrm{~m}^{-2}$ obtained for all searched locations. This approach endorse the results of the presented research method and also helps to validate the contents (CUB $\mathrm{m}^{-2}$ ) for Industrial Shed (IS) monthly published by the Union of the Construction Industry, as reference budgets for free-stall design as demonstrated.

\section{CONCLUSIONS}

The combination of various construction techniques, taking into account the regional input choice, provided a margin of approximately $29 \%$ of the construction total cost for the average capacity of 80 animals. For maximum capacity of 120 animals, it was obtained a reduction of $4.32 \%$ in the Basic Unit Cost $\left(\mathrm{BUC} \mathrm{m}^{-2}\right)$, and for the minimum capacity of 40 animals, an increase of $10.32 \%$ in the BUC m$~^{-2}$, justifying the need for expansion of the facility searching of a better cost benefit.

Thus, it can be concluded that the Basic Unit Cost $\left(\mathrm{BUC} \mathrm{m}^{-2}\right)$, for the different construction techniques showed in the survey, is a feasible indicator for analysis and investment forecasts, like the confinement systems of free-stall type, considering the best design practices and a more efficient and pre-designed environment for technological interventions, aiming the animals welfare, increasing the workers' self-esteem and, especially, for better production gain in volume and quality.

\section{REFERENCES}

BARBOSA SILVEIRA, I.D.; PETERS, M.D.P.; STORCH, T. ZIGUUER, E.A.; FISHER, V. Simulação da rentabilidade e viabilidade econômica de um modelo de produção de leite em freestall. Arquivo Brasileiro de Medicina Veterinária e Zootecnia, Belo Horizonte, v.63, n.2, p. 392398, 2011. Disponível em: < http://www.scielo.br/pdf/abmvz/v63n2/17.pdf>. Acesso em: 18 maio 2015.

CARDOSO, R.S. Orçamento de obras em foco: um novo olhar sobre a engenharia de custos. 2 ed. São Paulo: Pini, 2011. p. 1-498.

CECCHIN, D.; CAMPOS, A.T.; PIRES, M. de F.A.; LIMA, R. R. de; YANAGI JÚNIOR, T.; SOUZA, M.C.M. Avaliação de diferentes materiais para recobrimento de camas em baias de galpão modelo free-stall. Revista Brasileira de Engenharia Agrícola e Ambiental, Campina Grande, v.18, n.1, p.109-115, 2014.

COOK, N.B.; NORDLUND, K.V. The influence of the environment on dairy cow behavior, claw health and herd lameness dynamics. The Veterinary Journal, Madison, v.179, n.3, p.360-369, 2009.

CORDOBA, J.D.; CASILLOB, M.P.; ORMEÑOB, N.; ACOSTAC, G.; TADICHB, N. Descripción de los cubículos utilizados en granjas lecheras en el sur de Chile y su relación con el confort de las vacas. Archivos de Medicina Veterinária, Valdivia, v.44, n.1, p.75-80, 2012. 
IBGE - INSTITUTO BRASILEIRO DE GEOGRAFIA E ESTATÍSTICA. Censo agropecuário. Rio de Janeiro: Instituto Brasileiro de Geografia e Estatística, 2011.

LOPES, M.A.; SANTOS, G. dos; CARVALHO, F. de M. Comparativo de indicadores econômicos da atividade leiteira de sistemas intensivos de produção de leite no Estado de Minas Gerais. Revista Ceres, Viçosa, MG, v.59, n.4, p.742-752, 2012.

MATTOS, A. D. Planejamento e controle de obras. São Paulo: Ed. Pini, 2010. 419p.

MILANI, A.P.; SOUZA, F.A. de. Granjas leiteiras na região de Ribeirão Preto - SP. Engenharia Agrícola, Jaboticabal, v.30, n.4, p.742-752, 2010.

MITEV, J.; VARLYAKOV, I.; MITEVA, T.; VASILEV, N.; GEORGOVSKA, J.; UZUNOVA, K.; DIMOVA, V. Preferences of freestall housed dairy cows to different bedding materials. Journal of the Faculty of Veterinary Medicine Istanbul University, Istanbul, v.38, p.135-140, 2012.

PERISSINOTTO, M.; MOURA, D.J.; CRUZ, V.F.; SOUZA, S.R.L. de; LIMA, K.A.O. de; MENDES, A.S. Conforto térmico de bovinos leiteiros confinados em clima subtropical e mediterrâneo pela análise de parâmetros fisiológicos, utilizando a teoria dos conjuntos fuzzy.

Ciência Rural, Santa Maria, v.39, n.5, p.1.492-1.498, 2009.

MECHI, A.; SANCHES, D.L. Impactos ambientais da mineração no Estado de São Paulo. Estudos Avançados, v.24, n.68, p. 209-220, 2010. Disponível em:

<http://www.scielo.br/pdf/ea/v24n68/16.pdf>. Acesso em: 19 maio 2015.

PIRES, M. de F.A.; CASTRO, C.R.T. de; PACIULLO, D.S.; XAVIER, D.F. Importância da sombra para ruminantes nos trópicos. In: JORNADA DA PRODUÇÃO ECOLÓGICA DE RUMINANTES NO SEMIÁRIDO, 2011, Mossoró. Anais... Mossoró: UFERSA, 2011. p.64-90.

RAMOS, M.C.; CAMPOS, A.T.; SILVA, K.C.P da; YANAGI JÚNIOR, T.; GOMES, F.C.

Sustentabilidade na produção de leite: balanço energético em sistema intensivo de produção com visão focada nos processos. Engenharia Agrícola, Jaboticabal, v.34, n.3, p.473-484, 2014.

RUUD, L.E.; KIELLAND, C.; ØSTERÁS, O.; BØE, K.E. Free-stall cleanliness is affected by stall design. Livestock Science, Amsterdam, v.135, n.2-3, p.265-273, 2010.

SAMPAIO, C.A. de P.; CARDOSO, C.O.; SOUZA, G.P. de. Temperaturas superficiais de telhas e sua relação com o ambiente térmico. Engenharia Agrícola, Jaboticabal, v.1, n.2, p.230-236, 2011.

SANTOS, A.P.L.; WITICOVSKI, L.C.; GARCIA, L.E.M.; SCHEER, S. A utilização do BIM em projetos de construção civil. Revista Iberoamericana de Engenharia Industrial, Florianópolis, v.1, n.2, p.24-42, 2009.

SINDUSCON - SINDICATO DA INDÚSTRIA DA CONSTRUÇÃO CIVIL DO ESTADO DE GOIÁS. Custo unitário básico da construção. Goiás. abr. 2014. Disponível em: < http://www.sinduscongoias.com.br/arquivos/download/cub/cub-abril-2014.pdf >. Acesso em: 13 maio 2014.

SINDUSCON - SINDICATO DA INDÚSTRIA DA CONSTRUÇÃO CIVIL DO ESTADO DE MINAS GERAIS. Custo unitário básico da construção. Belo Horizonte, abr. 2014. Disponível em: < http://www.sinduscon-mg.org.br/site/arquivos/up/cub/tabelas/ tabela_cub_desonerado_abril_2014.pdf $>$. Acesso em: 13 maio 2014.

SINDUSCON - SINDICATO DA INDÚSTRIA DA CONSTRUÇÃO CIVIL DO ESTADO DO PARANÁ. Custo unitário básico da construção. Curitiba, abr. 2014. Disponível em: < http://www.sinduscon-pr.com.br/principal/pub/Image/20140502170548CUB-

PR_Abril_2014_desonerado.pdf>. Acesso em: 13 maio 2014.

SINDUSCON - SINDICATO DA INDÚSTRIA DA CONSTRUÇÃO CIVIL DO ESTADO DE SÃO PAULO. Custo unitário básico da construção. São Paulo, abr. 2014. Disponível em: < http://www.sindusconsp.com.br/downloads/estprod/economia/2014/04_boletimEconomico_desoner ado_abril2014.pdf>. Acesso em: 13 maio 2014. 
STOCK, L.A; CARNEIRO, A.V.; CARVALHO, G.R.; ZOCCAL, R.; MARTINS, P.C.;

YAMAGUCHI, L.C.T. Sistemas de produção e sua representatividade na produção de leite no Brasil. In: REUNIÃO DA ASSOCIAÇÃO LATINO-AMERICANA DE PRODUÇÃO ANIMAL, 2008, Cuzco. Anais...ALPA, 2008. p.17-18.

OSTOJIĆ-ANDRIĆ, D.; HRISTOV, S.; NOVAKOVIĆ, Ž.; PANTELIĆ, V.; PETROVIĆ, M.M.; ZLATANOVOIĆ, Z.; NIKŠIĆ, D. Dairy cows welfare quality in loose vs tie housing system.

Institute for Animal Husbandry, Belgrade-Zemun, v.27, n.3, p.975-984, 2011.

TCPO. TCPO14 Edificações: tabelas de composição de preços para orçamentos. São Paulo: Pini, 2014. 640p.

TISAKA, M. Orçamento na construção civil: consultoria, projeto e execução. 2 ed. São Paulo: Pini, 2011. 470p.

TONOLI, G.H.D.; SANTOS, S.F. dos; RABI, J.A.; SANTOS, W.N. dos; SAVASTANO JÚNIOR, H. Thermal performance of sisal fiber-cement roofing tiles for rural constructions. Scientia Agricola, Piracicaba, v. 68, n.1, p.1-7, 2011. 